\title{
NUP107 Gene
}

National Cancer Institute

\section{Source}

National Cancer Institute. NUP107 Gene. NCI Thesaurus. Code C101487.

This gene is involved in the assembly of the nuclear pore complex. 